E International

\title{
Shinkansen investment before and after JNR Reform
}

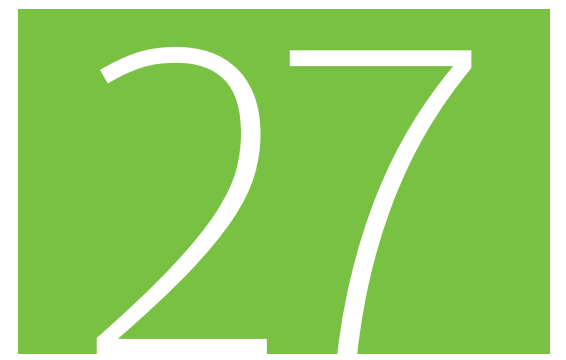

Discussion Paper 2013 27

Fumio Kurosaki

Institute of Transportation

Economics, Tokyo, Japan 



\title{
International Transport Forum
}

\section{Shinkansen Investment Before and After JNR Reform}

\author{
Discussion Paper No. 2013-27
}

Prepared for the Roundtable on

The Economics of Investment in High-Speed Rail

(18-19 December 2013, New Delhi, India)

Fumio KUROSAKI

Institute of Transportation Economics, Tokyo, Japan

December 2013 
The International Transport Forum at the OECD is an intergovernmental organisation with 54 member countries. It acts as a strategic think-tank, with the objective of helping shape the transport policy agenda on a global level and ensuring that it contributes to economic growth, environmental protection, social inclusion and the preservation of human life and well-being. The International Transport Forum organises an annual summit of Ministers along with leading representatives from industry, civil society and academia.

The International Transport Forum was created under a Declaration issued by the Council of Ministers of the ECMT (European Conference of Ministers of Transport) at its Ministerial Session in May 2006 under the legal authority of the Protocol of the ECMT, signed in Brussels on 17 October 1953, and legal instruments of the OECD.

The Members of the Forum are: Albania, Armenia, Australia, Austria, Azerbaijan, Belarus, Belgium, Bosnia and Herzegovina, Bulgaria, Canada, Chile, People's Republic of China, Croatia, Czech Republic, Denmark, Estonia, Finland, France, Former Yugoslav Republic of Macedonia, Georgia, Germany, Greece, Hungary, Iceland, India, Ireland, Italy, Japan, Korea, Latvia, Liechtenstein, Lithuania, Luxembourg, Malta, Mexico, Republic of Moldova, Montenegro, the Netherlands, New Zealand, Norway, Poland, Portugal, Romania, Russian Federation, Serbia, Slovak Republic, Slovenia, Spain, Sweden, Switzerland, Turkey, Ukraine, United Kingdom and United States.

The International Transport Forum's Research Centre gathers statistics and conducts co-operative research programmes addressing all modes of transport. I ts findings are widely disseminated and support policymaking in Member countries as well as contributing to the annual summit.

\section{Discussion Papers}

The International Transport Forum's Discussion Paper Series makes economic research, commissioned or carried out at its Research Centre, available to researchers and practitioners. The aim is to contribute to the understanding of the transport sector and to provide inputs to transport policy design.

ITF Discussion Papers should not be reported as representing the official views of the ITF or of its member countries. The opinions expressed and arguments employed are those of the authors.

Discussion Papers describe preliminary results or research in progress by the author(s) and are published to stimulate discussion on a broad range of issues on which the ITF works. Comments on Discussion Papers are welcomed, and may be sent to: International Transport Forum/OECD, 2 rue André-Pascal, 75775 Paris Cedex 16, France.

For further information on the Discussion Papers and other JTRC activities, please email: itf.contact@oecd.org

The Discussion Papers can be downloaded from:

www. internationaltransportforum. org/jtrc/DiscussionPapers/jtrcpapers.html

The International Transport Forum's website is at: www. internationaltransportforum.org

This document and any map included herein are without prejudice to the status of or sovereignty over any territory, to the delimitation of international frontiers and boundaries and to the name of any territory, city or area. 


\title{
1. INTRODUCTION
}

\begin{abstract}
"Shinkansen" refers to Japan's dedicated high-speed intercity rail system, and it was initially introduced between Tokyo and Shin-Osaka in 1964 prior to other countries. This event accelerated the development of high-speed railways in other countries. In Japan its total length and the number of lines have increased since then contributing to the economic development of the country. As with other conventional railways, Shinkansen was constructed and operated by the Japanese National Railways (JNR).
\end{abstract}

There is another issue which Japan's railway experienced prior to other countries, namely railway reform which was implemented in April 1987. This separated JNR into six independent passenger railway companies. Since then, the financial resources for Shinkansen construction were modified so as not to worsen the financial situation of the new companies, and public finances have been utilised in order to extend the lines. Even after separation into independent companies, operation of Shinkansen trains, including through-service trains crossing borders between companies, has been smooth. This article outlines how construction and operation of Shinkansen lines has been modified through JNR reform.

As Shinkansen lines have been built in various markets in Japan over a half century, traffic volume varies greatly depending on the line. Based on published data, this paper examines the changes to high-speed rail transport and appraises its outcomes including the financial aspects of the operating companies.

\section{OUTLINE OF JNR REFORM}

This section outlines the history of JNR and background to JNR reform. In 1949, the government reorganised the railways and established the Japanese National Railways (JNR) as a public enterprise. Due to the lack of other means of transport, the railways dominated post-war passenger and freight markets in Japan. In 1950, Japanese railways had 92 percent of the passenger market (passenger-km) and 52 percent of the freight market (tonne-km), and they continued making profits through the 1950s and early 1960 s (Aoki et al., 2000 p.181). However, from the 1960s, motorisation and air transport progressed dramatically in tandem with the high economic growth, and the modal share of railways decreased.

Owing to the competitiveness of other modes of transport, JNR continued to lose its freight businesses along with local passenger transport. In addition, JNR shouldered the burden of construction costs of new railway lines. Thus, JNR ran a deficit in 1964 and the annual deficit continued for many subsequent years. JNR accumulated long-term debt 
each year, and at the time of JNR reform in 1987 it amounted to 25 trillion yen, which was roughly equivalent to the combined national debts of several developing countries (ibid, p.183).

In addition to financial difficulties, JNR also faced severe criticism of its ineffective management. Thus, JNR reform was finally undertaken in April 1987. Through the reform, JNR was split into six regional passenger companies and a single nation-wide freight company (JR Freight). (Figure 1)

Figure 1. JNR Reform in 1987

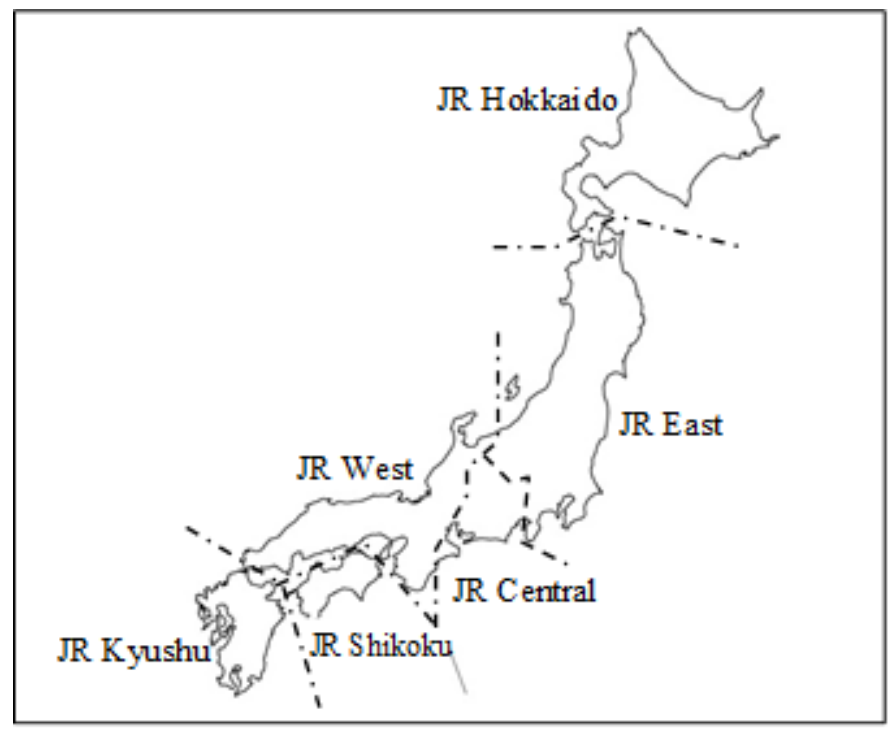

\section{SHINKANSEN PROJECTS IN JNR AND ITS MANAGEMENT}

\subsection{Shinkansen Projects before JNR Reform}

An original aim of constructing Shinkansen lines in Japan was to accommodate increasingly heavy traffic demand along the trunk lines. Although the gauge of Japanese conventional lines is $1067 \mathrm{~mm}$, it was decided that Shinkansen lines would be constructed with a standard gauge of $1435 \mathrm{~mm}$ after serious discussions among concerned persons. Along with technology that permitted higher speed, construction of a dedicated track for high-speed passenger trains made it possible to operate a larger number of trains. At present, high-speed trains are operated with a 3-minute train headway during the peak hours in the Tokaido Shinkansen Line, and this kind of concentrated train operation could not have been realised if the track had to be shared with slower conventional and freight trains.

The first Shinkansen project connecting Tokyo and Shin-Osaka started construction work in 1959 and was opened in October 1964. Traffic volume increased steadily, and the number of trains was also increased. Following the first line, the Tokaido Shinkansen Line, JNR constructed the second high-speed line, namely, the Sanyo Shinkansen Line. 
The section between Shin-Osaka and Okayama opened in 1972, extended to Hakata in 1975.

Although the original aim was to overcome the capacity constraints of the trunk lines, as mentioned above, the success of the Tokaido and Sanyo Shinkansen Lines aroused the local interest to extend Shinkansen lines to other cities, focusing on its high speed rather than transport capacity. As a result, the government promulgated the Nationwide Shinkansen Development Law in 1970, and planned a nationwide Shinkansen network (ibid. p.144). This plan proposed to construct a Shinkansen network with a total of more than $68000 \mathrm{~km}$.

Prior to JNR reform, both conventional and Shinkansen lines had been constructed with interest-bearing loans. This means that it was a precondition that the construction costs be paid back from sales revenue after the opening of operations. Owing to the financial constraints, JNR could not allow a large investment to construct new Shinkansen lines. Nevertheless, construction work steadily continued, and the Tohoku and Joetsu Shinkansen Lines were opened before JNR reform, bringing the network of Shinkansen lines to $2031.9 \mathrm{~km}$ in 1987 (Table 1).

Table 1. Shinkansen Lines Completed before JNR Reform

\begin{tabular}{|c|c|c|c|c|}
\hline & Shinkansen Line & $\begin{array}{c}\text { Section } \\
\text { (Operating Company } \\
\text { after JNR Reform) }\end{array}$ & $\begin{array}{l}\text { Operating Line } \\
\text { Length }\end{array}$ & Date Open \\
\hline 1) & Tokaido Shinkansen & $\begin{array}{c}\text { Tokyo - Shin-Osaka } \\
\text { (JR Central) }\end{array}$ & $552.6 \mathrm{~km}$ & 1 Oct. 1964 \\
\hline 2a) & Sanyo Shinkansen & $\begin{array}{c}\text { Shin-Osaka - Okayama } \\
\text { (JR West) }\end{array}$ & $180.3 \mathrm{~km}$ & 15 Mar. 1972 \\
\hline 2b) & Sanyo Shinkansen & $\begin{array}{c}\text { Okayama - Hakata } \\
\text { (JR West) }\end{array}$ & $463.7 \mathrm{~km}$ & 10 Mar. 1975 \\
\hline 3a) & Tohoku Shinkansen & $\begin{array}{l}\text { Omiya - Morioka } \\
\text { (JR East) }\end{array}$ & $505.0 \mathrm{~km}$ & 23 Jun. 1982 \\
\hline 3b) & Tohoku Shinkansen & $\begin{array}{c}\text { Ueno - Omiya } \\
\text { (JR East) }\end{array}$ & $26.7 \mathrm{~km}$ & 14 Mar. 1985 \\
\hline 4) & Joetsu Shinkansen & $\begin{array}{l}\text { Omiya - Niigata } \\
\text { (JR East) }\end{array}$ & $303.6 \mathrm{~km}$ & 15 Nov. 1982 \\
\hline \multicolumn{3}{|c|}{ Total Length of Shinkansen Lines in 1987} & $2031.9 \mathrm{~km}$ & \\
\hline
\end{tabular}

Source: MLIT (2013) 
Figure 2. Shinkansen Network: 1987

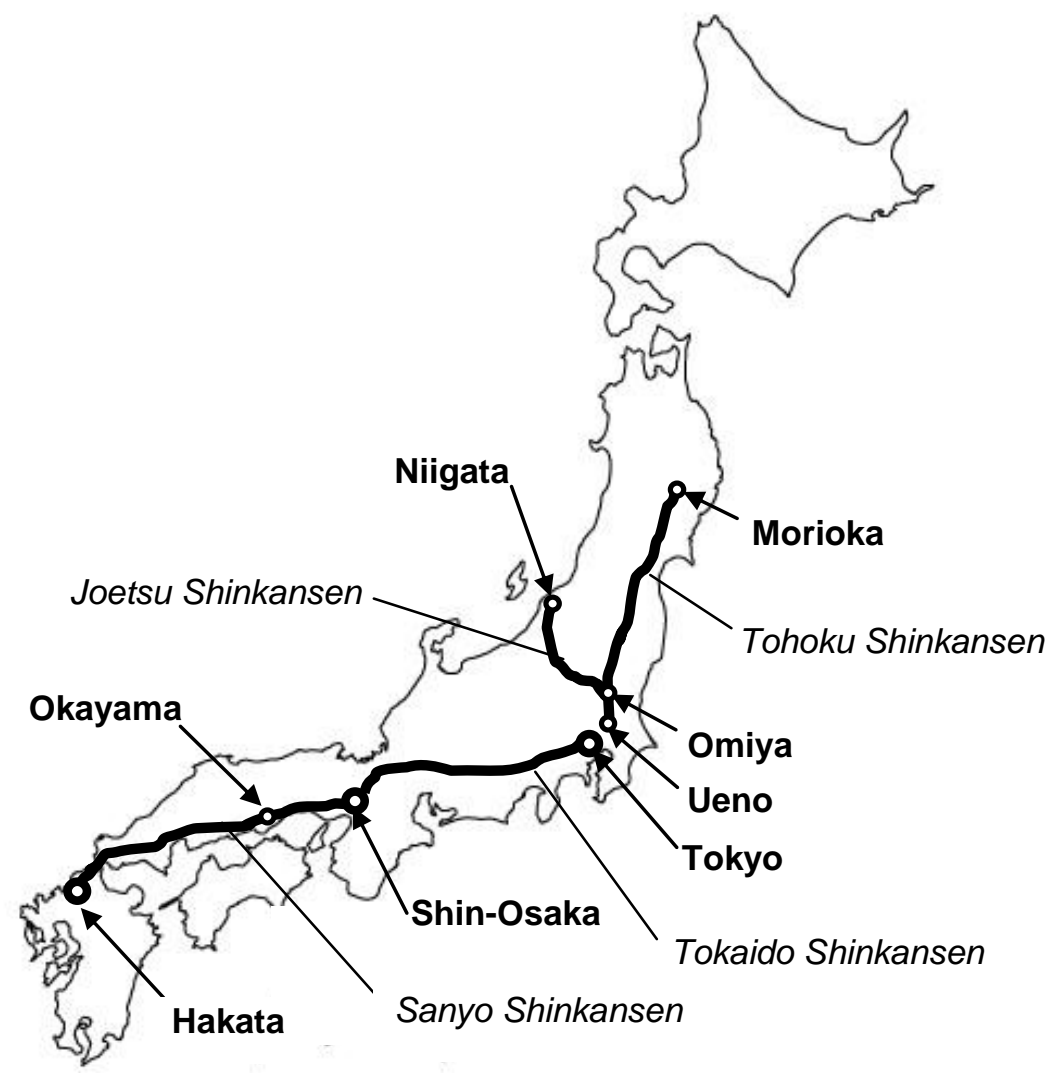

\subsection{Shinkansen Performance during JNR Era}

This section examines the performance of Shinkansen lines opened during the JNR era. Table 2 shows the transport performance of Shinkansen Lines from 1982 to 1984.

Table 2. Transport Results of Shinkansen Lines (1982-1984)

\begin{tabular}{|c|c|c|c|c|c|}
\hline Item & Unit & Line name & 1982 & 1983 & 1984 \\
\hline \multirow[t]{3}{*}{ Number of Passengers } & \multirow[t]{3}{*}{ thousands } & Tokaido \& Sanyo & 124830 & 127613 & 128363 \\
\hline & & Tohoku & 14000 & 23409 & 24127 \\
\hline & & Joetsu & 4077 & 10327 & 11300 \\
\hline \multirow{3}{*}{$\begin{array}{l}\text { Transport Volume } \\
\text { (passenger km) }\end{array}$} & \multirow[t]{3}{*}{ millions } & Tokaido \& Sanyo & 41489 & 42186 & 42197 \\
\hline & & Tohoku & 3743 & 5989 & 6142 \\
\hline & & Joetsu & 873 & 2265 & 2487 \\
\hline \multirow{3}{*}{$\begin{array}{l}\text { Traffic Density } \\
\text { (passengers/day) }\end{array}$} & \multirow[t]{3}{*}{ thousands } & Tokaido \& Sanyo & 95.0 & 96.6 & 96.6 \\
\hline & & Tohoku & 26.3 & 32.5 & 33.3 \\
\hline & & Joetsu & 21.0 & 20.4 & 22.4 \\
\hline
\end{tabular}

Source: JNR (1985)

It is very difficult to allocate correctly the overhead expenses by line. But, in the latter period of JNR, in order to analyse management of JNR in preparation for reform, an audit report analysed the profitability of the lines. 
Based on the report, the transport and financial results of operating Shinkansen lines are shown in Table 3.

Table 3. Financial Results for Shinkansen Lines (1982 - 1984)

\begin{tabular}{|c|c|c|c|c|}
\hline & & & \multicolumn{2}{|c|}{ Unit: billion yen } \\
\hline Name of Lines & Accounts & 1982 & 1983 & 1984 \\
\hline \multirow[t]{3}{*}{ Tokaido \& Sanyo } & 1) Operating Revenue & 816.1 & 829.9 & 893.1 \\
\hline & 2) Operating Expenses & 343.8 & 342.9 & 348.2 \\
\hline & 3) Operating Profit & 472.3 & 487.0 & 544.9 \\
\hline \multirow[t]{3}{*}{ Tohoku \& Joetsu } & 1) Operating Revenue & 104.5 & 187.7 & 206.7 \\
\hline & 2) Operating Expenses & $\begin{array}{r}43.6 \\
{[160.3]}\end{array}$ & $\begin{array}{r}69.1 \\
{[283.2]}\end{array}$ & $\begin{array}{r}76.5 \\
{[298.8]}\end{array}$ \\
\hline & 3) Operating Profit & $\begin{array}{r}60.9 \\
{[-55.8]}\end{array}$ & $\begin{array}{r}118.6 \\
{[-95.5]}\end{array}$ & $\begin{array}{r}130.2 \\
{[-92.1]}\end{array}$ \\
\hline
\end{tabular}

[ ]: Indicates total expenses/profit including depreciation and other capital costs.

Source: JNR (1985)

The above table shows that the Tokaido and Sanyo Shinkansen Lines were very profitable, though there is no data which includes expenses of capital costs. JNR (1986) also noted that the Tokaido and Sanyo Shinkansen Lines were the second most profitable lines within JNR network following the Yamanote Line, which operates in the center of the Tokyo metropolitan area.

Regarding the Tohoku and Joetsu Lines, the above table shows that, although they were profitable if capital costs related to infrastructure were not included, the inclusion of those costs resulted in net loss.

\subsection{JNR Reform and Transfers of Shinkansen Assets}

In JNR reform, Shinkansen operation was divided among the three Honshu JR passenger companies: JR East, JR Central, and JR West. Nevertheless, it was assumed that profit adjustment among the three companies would be indispensable. Accordingly, Shinkansen Holding Corporation (SHC) was established, which owned the assets of the Shinkansen infrastructure and also shouldered the same amount of debt as their market-based revaluation. Then, each line was leased for operation to each of the three JR companies, and the above-mentioned profit adjustment was realised through the amount of lease charges paid (Sumita, 2005).

Nevertheless, although the three companies had aimed to become listed companies, this organisational structure faced a disadvantage in that the assets of the companies would be indefinite even if they finished paying the lease fees in the future. In addition, as the JR companies did not retain ownership of their infrastructure assets, it was impossible for them to reserve for depreciation, and even the investment for infrastructure assets had to be treated as an expenditure of a single year rather than depreciated over several years.

In order to resolve these issues, the assets of the Shinkansen infrastructure were sold to the three JR companies in October 1991, and SHC was dissolved. Since then, the three JR companies have retained ownership of Shinkansen infrastructure assets which had 
been constructed during the JNR era. Thus, unlike new Shinkansen lines which have been constructed/opened since JNR reform, these initial Shinkansen lines constructed before 1987 have been operated by an integrated structure since the sale of the assets in 1991 .

\section{SHINKANSEN PROJECTS SINCE JNR REFORM}

\subsection{Finance and Management of New Shinkansen Lines}

Even since JNR reform, construction works have been implemented to extend Shinkansen lines. A construction and operation scheme for these works was modified reflecting the management failures of JNR. Since JNR reform, the new lines and extensions of Shinkansen lines have been constructed and operated based on the new scheme, and Japan Railway Construction, Transport and Technology Agency (JRTT), a wholly government-financed entity, carries out Shinkansen construction works as public projects.

JRTT not only implements construction work but also retains ownership of the infrastructure assets after completion of the projects. It leases the assets to the JR passenger companies, which provide high speed railway services. Thus, different from the initial Shinkansen lines which had been constructed during the JNR era, the newly constructed sections form a vertically separated structure. The JR companies pay usage fees based on the calculation explained in the following section. Regarding financial resources, except for the usage fees which would be allocated for construction works, the current financial scheme, which was revised in 1996, stipulates that the state and local governments bear the financial burden of the projects by a ratio of $2: 1$.

\subsection{Usage Fees and Maintenance Costs}

The amount of usage fees paid by an operator of new Shinkansen lines is an essential factor in the relationship between the JR passenger company and the public sector.

Payment of usage fees is regulated by the Japan Railway Construction, Transport and Technology Agency Law. The Law stipulates that JRTT basically calculates the amount based on the benefits received as an operator of the new Shinkansen lines after opening. The above-mentioned benefits are calculated by comparing the following two amounts:

1. the estimated revenues and expenses generated by the new Shinkansen lines and related line segments after opening; with

2. the estimated revenues and expenses that would likely be generated by parallel conventional lines and related line segments if the new Shinkansen lines were not opened.

In brief, the amount equals to the operator's net increase of benefits through the commencement of operation. Then, the above-mentioned amounts are calculated based on expected revenue and expenses over a 30 -year period after opening. 
As a rule, in commencing the construction works, the local communities are to agree to separate the management of the conventional lines parallel to newly constructed Shinkansen lines from the JR companies. Since these conventional lines are unprofitable, this separation alleviates the financial burden of JR companies, and in general the regional governments are to manage the railways including their finances if they wish to continue the operation.

As for expenses of JR companies, the taxes and maintenance fees are included in the above-mentioned calculations. As such, the scheme is designed so that the operation of newly constructed Shinkansen lines should not worsen the financial situation of the JR passenger companies and the burden of the operator would be kept within the limits of the benefits received as an operator of new lines (JR East, 2004).

Regarding payment of maintenance costs of infrastructure, each JR passenger company pays within its own budget. Although both new Shinkansen lines and European railways form vertically separated structures, the payment of the maintenance costs shows a stark contrast. For railways in Europe, an infrastructure manager pays the maintenance costs, although the amount of usage fees can cover the maintenance costs in some cases. However, in the case of Japan, the infrastructure owner (JRTT) does not pay any cost for operation and maintenance works of the infrastructure, and received usage fees are utilised for a part of construction costs of other projects.

The above-mentioned new scheme for constructing Shinkansen line is accepted by concerned parties, since, in theory, a JR company neither gains nor loses because of the projects promoted as public works.

\subsection{Sections of New Shinkansen Lines}

Based on the schemes explained in the above sections, construction work continued even after JNR reform. Table 4 shows new segments of Shinkansen lines which have opened since JNR reform.

Table 4. New Shinkansen Lines Opened Since JNR Reform

\begin{tabular}{|l|c|c|c|}
\hline Shinkansen Line & $\begin{array}{c}\text { Section } \\
\text { (Operating Company) }\end{array}$ & $\begin{array}{c}\text { Operating Line } \\
\text { Length }\end{array}$ & Date of Opening \\
\hline 1a) Tohoku Shinkansen & $\begin{array}{c}\text { Tokyo - Ueno } \\
\text { (JR East) }\end{array}$ & $3.6 \mathrm{~km}$ & 20 Jun. 1991 \\
\hline 1b) Tohoku Shinkansen & $\begin{array}{c}\text { Morioka - Hachinohe } \\
\text { (JR East) }\end{array}$ & $96.6 \mathrm{~km}$ & 1 Dec. 2002 \\
\hline 1c) Tohoku Shinkansen & Hachinohe - Shin-Aomori \\
(JR East) & $81.8 \mathrm{~km}$ & 4 Dec. 2010 \\
\hline 2) Hokuriku Shinkansen & $\begin{array}{c}\text { Takasaki - Nagano } \\
\text { (JR East) }\end{array}$ & $117.4 \mathrm{~km}$ & 1 Oct.1997 \\
\hline 3a) Kyushu Shinkansen & $\begin{array}{c}\text { Hakata - Shin-Yatsushiro } \\
\text { (JR Kyushu) }\end{array}$ & $151.3 \mathrm{~km}$ & 12 Mar. 2011 \\
\hline 3b) Kyushu Shinkansen & $\begin{array}{c}\text { Shin-Yatsushiro - Kagoshima-Chuo } \\
\text { (JR Kyushu) }\end{array}$ & $137.6 \mathrm{~km}$ & 13 Mar. 2004 \\
\hline Total length of Shinkansen lines opened after 1987 & $588.3 \mathrm{~km}$ & \\
\hline
\end{tabular}

Source: MLIT (2013) 
In addition, the government has already permitted the promotion of other construction projects, and the following lines are now under construction:

1) Hokkaido Shinkansen: Shin-Aomori - Sapporo $(360 \mathrm{~km})$

2) Hokuriku Shinkansen: Nagano - Tsuruga (353km)

3) Kyushu Shinkansen: Takeo-Onsen - Nagasaki $(66 \mathrm{~km})$

As for other Shinkansen lines/segments, although the government had planned to construct a nation-wide Shinkansen network as mentioned in Section 3.1, it has not yet permitted promotion of those construction projects.

\subsection{New Sections/Lines Financed by JR companies}

Besides the above-mentioned scheme, there are other projects which particular JR companies have been promoting. One of these is the Central Shinkansen Line, promoted by JR Central, and another is Mini-Shinkansen Lines promoted by JR East.

\section{Central Shinkansen Line}

The financial schemes for the Central Shinkansen Line between Tokyo and Osaka are completely different from the above Shinkansen lines, and JR Central made a decision to construct the section between Tokyo and Nagoya utilising its own financial resources. The technology of the Central Shinkansen is different from other Shinkansen lines; it will adopt Maglev technology. JR Central has been preparing for the project since the government's approval of the plan in May 2011 according to the government's new Shinkansen line plan.

\section{Mini-Shinkansen Lines}

Mini-Shinkansen lines are not covered by the government's new Shinkansen line plan. And, as the definition of Shinkansen in Japan stipulates that it does not have a level crossing with roads, mini-Shinkansen lines are not categorised as Shinkansen lines.

In order to provide faster service to cities not on the Shinkansen, JR East promoted two projects with its own finances:

1) Yamagata Shinkansen (section between Fukushima and Shinjo)

2) Akita Shinkansen (section between Morioka and Akita)

In these sections, the track gauge was changed from conventional-line $1067 \mathrm{~mm}$ gauge to standard gauge, so that trains with standard gauge bogies could run on those lines. JR East then started through-train services between dedicated high speed lines (which are standard gauge) and these modified sections by utilising rolling stock of the same carbody size as conventional trains.

As mini-Shinkansen lines are categorised as conventional lines, the Shinkansen statistics in this paper do not include their data. 
Figure 3. Sections Extended Since JNR Reform

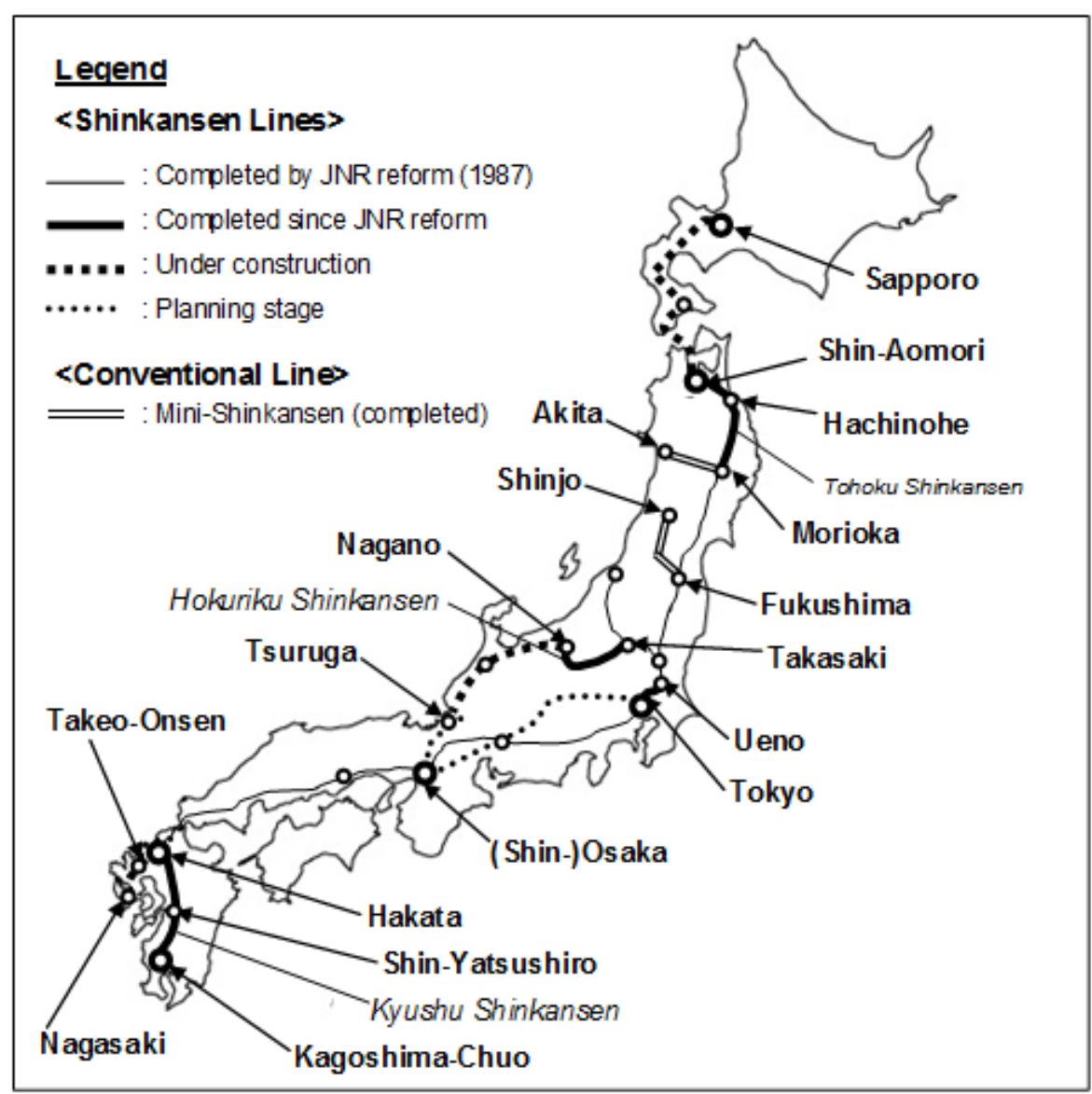

In summary, although construction projects of Shinkansen lines were implemented by JNR utilising interest-bearing loans, railway reform brought about a chance to revise that scheme, which was then modified so that the government would implement the projects and pay the construction costs of the infrastructure. Regarding construction of new Shinkansen lines, the public entity (JRTT) retains the ownership of the infrastructure and forms a vertically separated structure, so that the project does not affect the financial condition of JR companies.

Based on the above-mentioned schemes, the total Shinkansen operating line length has reached 2,620 km, and transport volume exceeded 80 billion passenger-km in 2011 . (Figure 4) 
Figure 4. Growth in Line Length and Transport Volume of Shinkansen Lines

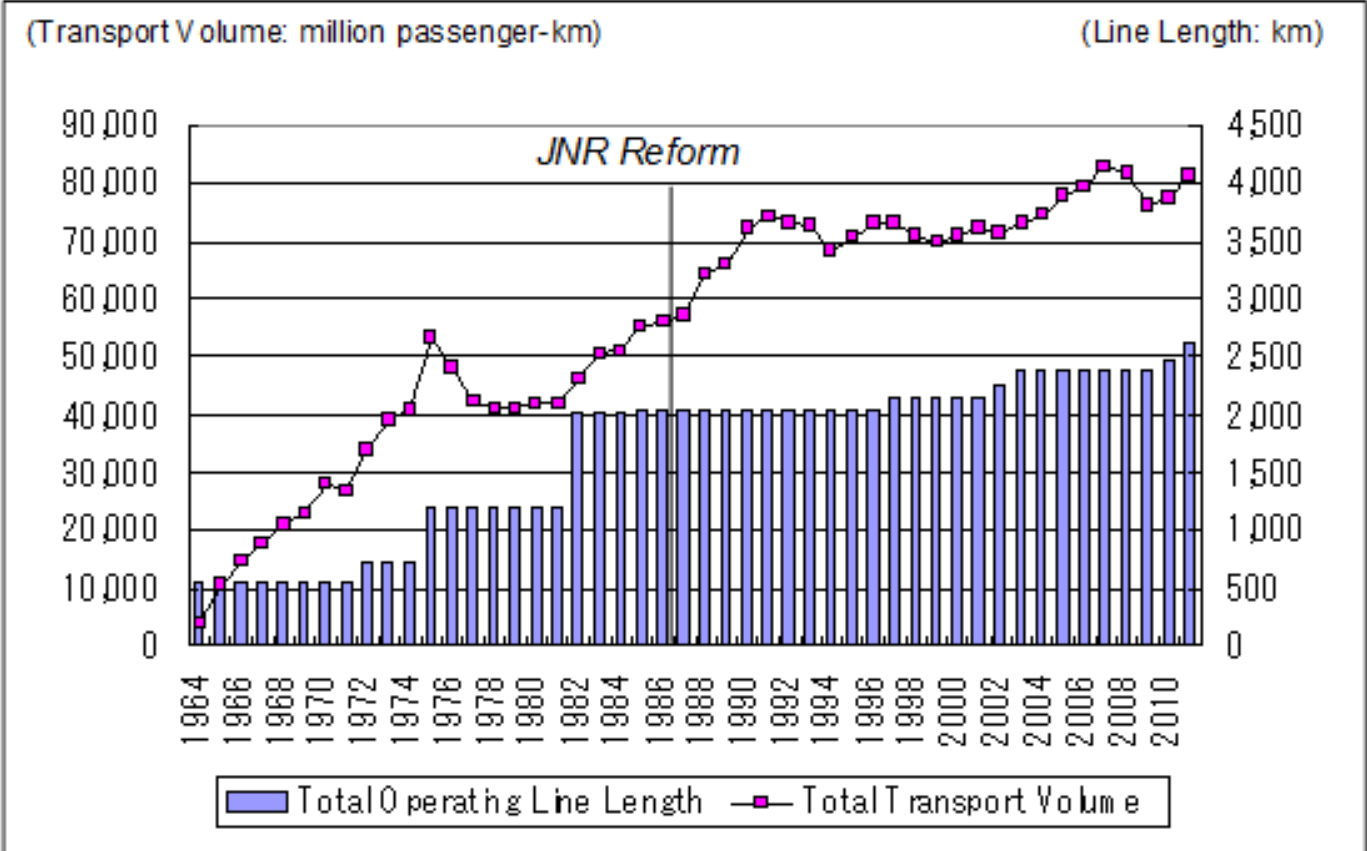

Source: Institute of Transportation Statistics (1995), MLIT (2013)

\section{CHARACTERISTICS OF TRAIN OPERATION IN JAPAN}

\subsection{Train Operation before JNR Reform}

During the JNR era, JNR in general owned the infrastructure and operated the trains. Since Shinkansen trains did not run through onto other railways, JNR took all responsibility of railway operation for all Shinkansen lines: Tokaido, Sanyo, Tohoku and Joetsu.

\subsection{Train Operation after JNR Reform}

The above-mentioned status changed at the time of JNR reform, and Shinkansen operation has also been taken over by the respective companies: JR East, JR Central and JR West. There has been no through-train service between the Tohoku/Joetsu (JR East) and Tokaido (JR Central) Shinkansen Lines because: 1 ) many passengers start/terminate their travel at Tokyo Station; and 2) their electric power supply systems are different. On the other hand, many trains run through between the Tokaido (JR Central) and Sanyo (JR West) Shinkansen Lines. Since the open of the Kyushu Shinkansen Line in March 2011, through-trains also operate between the Sanyo (JR West) and Kyushu (JR Kyushu) Shinkansen Lines.

Through-train services yield benefits for passengers, such as the reduction in travel time by omitting the need to change trains, as well as benefits for the railway companies by 
reducing terminal congestion for both passengers and trains. As the concerned railways can achieve these merits without heavy investment in the infrastructure, through-train services are common in Japan not only on Shinkansen lines but also on conventional lines.

These through-train services are operated in the same way for both Shinkansen trains and conventional trains in Japan, but in a completely different way from the recent European international / intercity trains. Thus, the operation of through-train services reveals one of the most distinct characteristics of train operation in Japan. Accordingly, this section explains how services are provided between two railway companies.

Briefly, through-train services in Japan are provided by two vertically integrated railways as outlined in Figure 5. This example shows through-train services between the Tokaido and Sanyo Shinkansen Lines.

Figure 5. Through-train Services Between Two Railway Companies in Japan

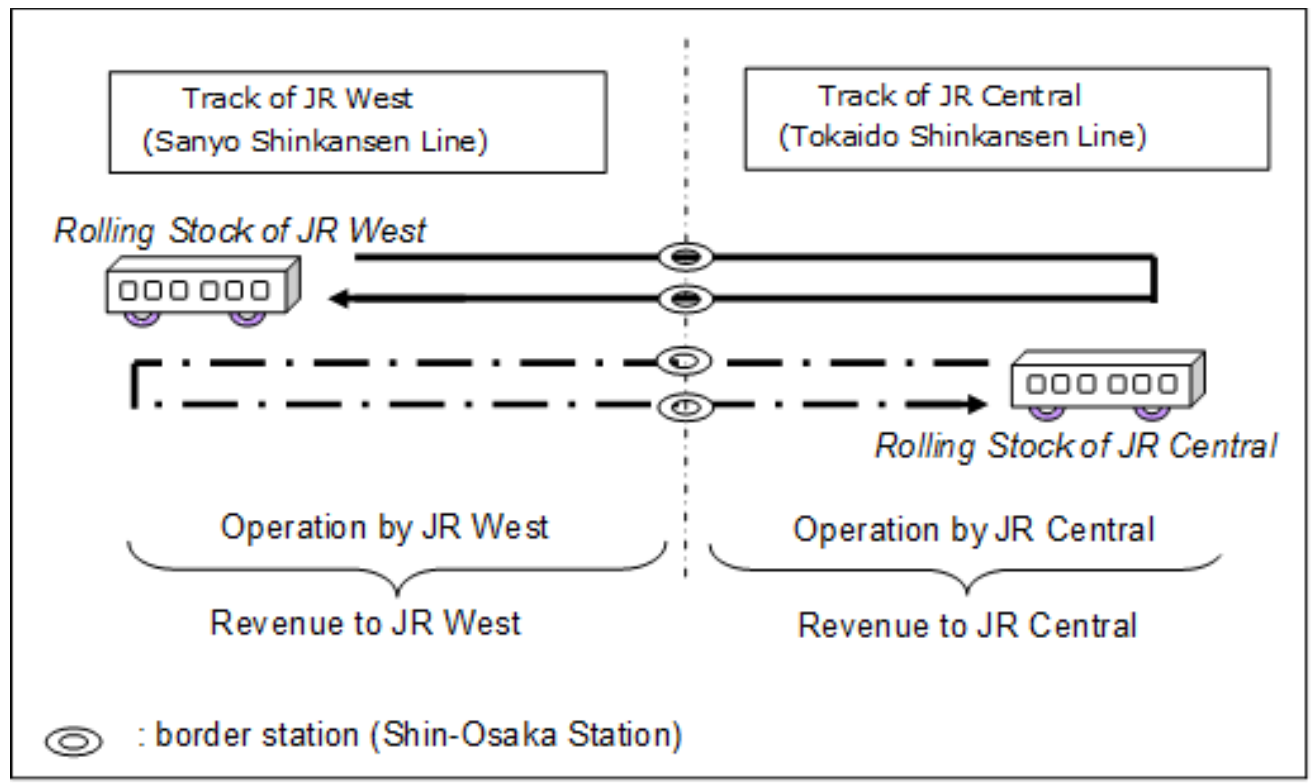

Source: Revised from Kurosaki (2008)

Since JNR reform, the Tokaido Shinkansen Line has been operated by JR Central, and the Sanyo Shinkansen Line by JR West. Although a number of trains start and terminate at the border station, Shin-Osaka, the two railway companies, JR Central and JR West, operate dozens of through-service Shinkansen trains per day.

For through-train services between the two railway companies, for example, a train owned by JR West leaves its own line and continues on the tracks of JR Central. The fares paid for travel using JR West's tracks belong to JR West even if JR West uses JR Central's rolling stock. When JR West uses JR Central's rolling stock, JR West pays rent-fees for the rolling stock to JR Central.

This kind of through-train operation is common not only on Shinkansen lines but also on conventional lines. As the railways arrange for access for other railways' rolling stock, before this service begins, the concerned railways negotiate about terms regarding the conditions of access. For example, they have to agree regarding rolling stock design and performance such as type of car body and bogie, electrical systems, signaling apparatus, 
train-control systems, weight of rolling stock, passenger capacity, brake performance, telecommunication systems, and safety measures. The two railways have to keep in close communication and promote understanding regarding their integrated schedule and rolling stock operation to avoid problems and accidents (Kurosaki, 2008).

For through-train services in Japan, the responsibilities in train operation are clearly separated at the border station, and each railway is fully responsible for train operation on its own tracks. As a rule, the drivers change at the border station and therefore drive trains only on their own network. This helps guarantee operational safety, and this kind of measure has become fundamental policy since a serious train accident occurred on the Shigaraki Highland Railway in 1991. Since this accident, in order to guarantee greater safety, each railway company has taken measures to more clearly distinguish its own operational responsibility from that of other railways. Similar to the Shinkansen trains shown above, most conventional inter-company trains, such as those between two JR passenger companies and those between a JR passenger company and a private railway, are operated in the same way (ibid.).

Taking the Shinkansen Lines from Tokyo Station to Kagoshima-Chuo Station for example, a number of trains operate crossing border stations between JR passenger companies. Nevertheless, operational responsibilities are clearly separated at the border stations, and each integrated railway company takes responsibility of train operation within its own network only, as shown in Figure 6.

Figure 6. Operational Responsibilities of the Three Shinkansen Lines

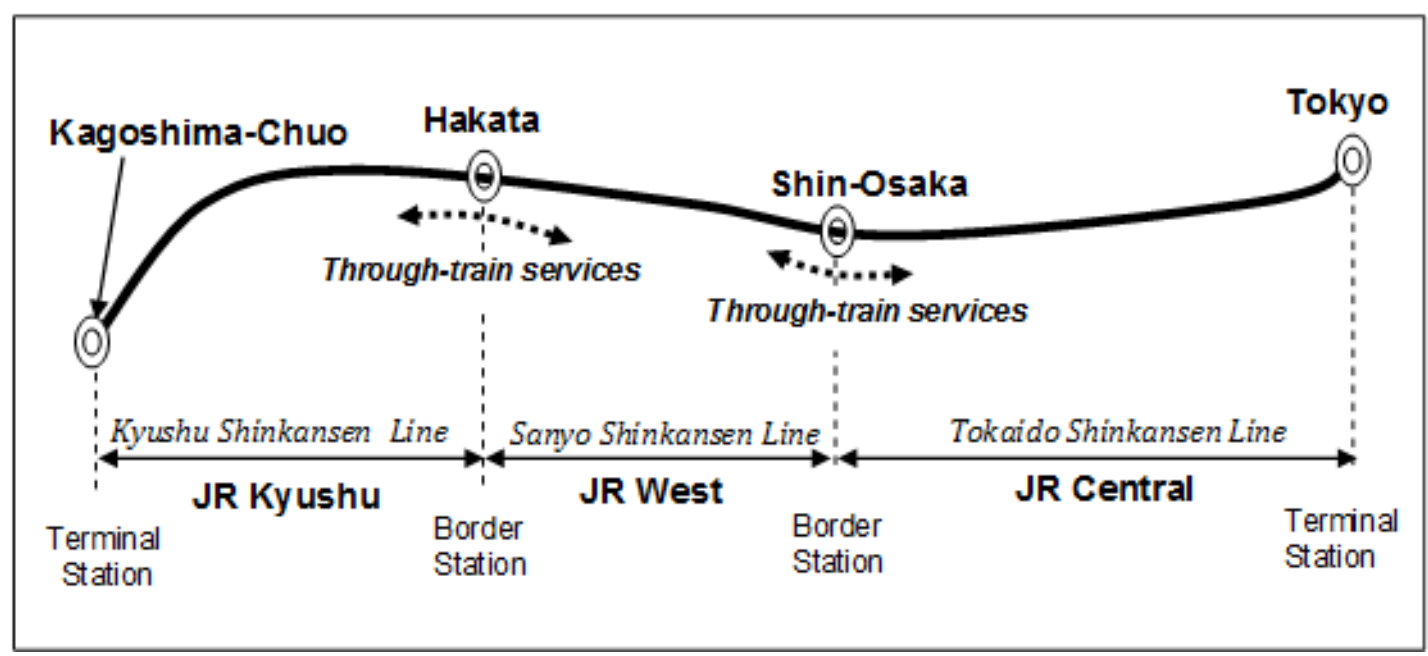

Source: Revised from "Kurosaki and Okuda (2012)"

As discussed in Section 4, vertical separation has been adopted in the sections which were constructed since JNR reform. Nevertheless, even in these sections, single railway company implements all operation, similar to an integrated railway. This integrated train operation is largely different from the recent case in European railways, where train operation has been separated into train operators and an infrastructure manager.

Both Shinkansen and conventional trains in Japan have gained a high reputation in terms of safety and punctuality even under conditions of very dense traffic. It should be noted that through-train services in Japan have been operated as described above, and there is no case of competition on the same track on any railway network in Japan. 


\section{CHANGES IN PERFORMANCE AND ITS EVALUATION}

\subsection{Changes in Transport Volume}

As discussed, construction of Shinkansen lines started from the most important trunk line with heavy congestion and was gradually extended to other outlying cities. Thus, conditions of transport market vary to a large extent, and transport volume of Shinkansen also differs between the initial line, the Tokaido Shinkansen Line, and other lines which were constructed later.

Figure 7 shows the changes of transport volume (passenger-km) of each line since JNR reform in 1987.

Figure 7. Changes in Transport Volume on Shinkansen Lines

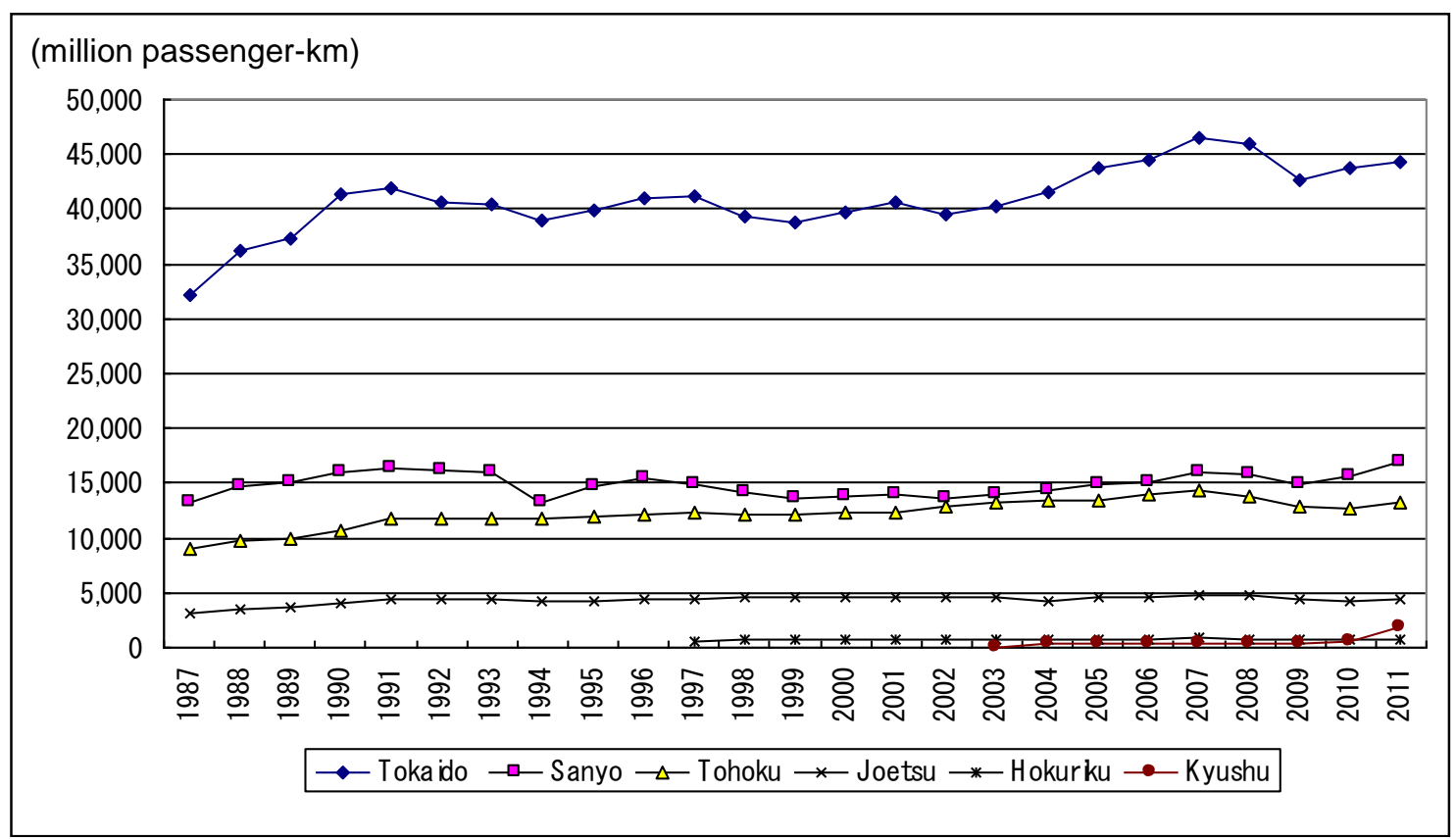

Source: MLIT (2013), JR West (2013), JR Central (2007; 2013a)

The Tokaido Shinkansen Line, which operates between Tokyo and Shin-Osaka, has the largest transport volume, and it has increased by $38 \%$ in the 24 years since JNR reform. Although transport volume of the Hokuriku Shinkansen Line, operating between Takasaki and Nagano, has remained level, all other Shinkansen Lines have increased in traffic volume since JNR reform or the line's opening. 


\subsection{Traffic Density and Management of the Lines}

Table 5 shows traffic density on each Shinkansen Line in 2011. Traffic density (passengers/day) can be calculated dividing transport volume (passenger-km) by the operating line length $(\mathrm{km})$ and operating days (normally 365 days). As shown, the traffic density also varies among these lines.

Table 5. Traffic Density of Shinkansen Lines in 2011 (Unit: thousand passengers/day)

\begin{tabular}{|c|c|c|}
\hline No. & Name of Shinkansen Line & Traffic Density \\
\hline 1 & Tokaido & 219.6 \\
\hline 2 & Sanyo & 71.8 \\
\hline 3 & Tohoku & 50.8 \\
\hline 4 & Joetsu & 39.6 \\
\hline 5 & Hokuriku & 17.8 \\
\hline 6 & Kyushu & 17.3 \\
\hline
\end{tabular}

Source: Calculation based on MLIT (2013), JR West (2013), JR Central (2013a)

It is very difficult to practically allocate the company's expenditure by line. Thus, since JNR reform, no JR company has publicised the revenue and expenditure by line. Thus, officially, the profitability of each line is unclear. But, according to Table 5, it is assumed that there are large differences in the profitability of each Shinkansen Line. In the following, the level of profitability is to be estimated based on the financial results of the operating company.

Firstly, it is certain that revenue from the Tokaido Shinkansen Line sufficiently covers operating expenses and depreciation of the assets, as JR Central has been profitable even though the company inherited a part of JNR's debt. As Section 3.3 noted, JR Central also bought Shinkansen infrastructure assets from SHC, and its long-term debt amounted to 5456 billion yen in 1991. But, this amount had decreased to 2615 billion yen by 2012 (JR Central, 2013b). The smoothness of this financial transition supports the above.

Secondly, it is also certain that the Sanyo Shinkansen Line gains profits with its sufficient traffic density. When JR West bought Shinkansen infrastructure assets from SHC in 1991 the long-term debt of JR West amounted to 1,595 billion yen. It has decreased to 973 billion yen by 2012 (JR West, 2013). As a number of local lines in JR West are not profitable, this financial transition shows that the Sanyo Shinkansen Line is profitable including capital costs and cross-subsidise unprofitable local lines.

Thirdly, regarding the Tohoku and Joetsu Shinkansen Lines, during the JNR era, they were profitable in operating cost but were not profitable when capital cost was included (JNR, 1985). As transport volume has increased significantly on some sections since then, it is assumed that the profitability has largely improved as well. In terms of the financial change of JR East, which operates Tohoku and Joetsu Shinkansen, its long-term debt amounted to 5378 billion yen when the company bought the assets of two Shinkansen Lines in 1991. Then, the debt had decreased annually and amounted to 3425 billion yen in March 2012 . Nevertheless, JR East operates a profitable network of Tokyo metropolitan area, and the operation of these conventional railways also contributes to the profits of the company. Thus, different from JR Central and JR West, above-mentioned financial transition does not necessarily verify that the two Shinkansen lines cover the capital costs. In addition, since the line provides long distance inter-city transport services, covering $714 \mathrm{~km}$ in the Tohoku 
Shinkansen Line and $304 \mathrm{~km}$ in the Joetsu Shinkansen Line, the level of traffic density of each section varies to a large extent as the following section shows. Thus, it is possible that the lines still have some unprofitable sections on which are difficult to cover the capital costs.

The level of traffic density of the Hokuriku and Kyushu Shinkansen Lines is less than half of that of the Joetsu Shinkansen Line, and it is not quite certain whether the operation of these lines covers the capital costs through the revenue. But, passengers on Shinkansen lines usually transfer to conventional lines, and the increase in ridership contributes to the profit of other lines. In addition, JR companies are active in promoting non-rail businesses such as real estate development around stations, operation of hotels and shopping center in their station buildings, etc. Passenger increase is also beneficial for promoting these nonrail businesses. Thus, it is possible that the operating company can report a profit with these related businesses. It is worth noting that the scheme, which was explained in Sections 4.1 and 4.2 , is not designed so that JR companies should cover capital costs in these lines, as JRTT had invested into the infrastructure and retains it.

\subsection{Changes in Traffic Density by Sections: A case of JR East}

JR East operates the Tohoku, Joetsu and Hokuriku Shinkansen Lines, and it publicises the level of traffic density of each section.

Figure 8 shows that they are largely different according to the distance from Tokyo. It is clear that the sections closer to Tokyo have larger traffic.

Figure 8. Traffic Density of the Tohoku Shinkansen Line (Passengers / day)

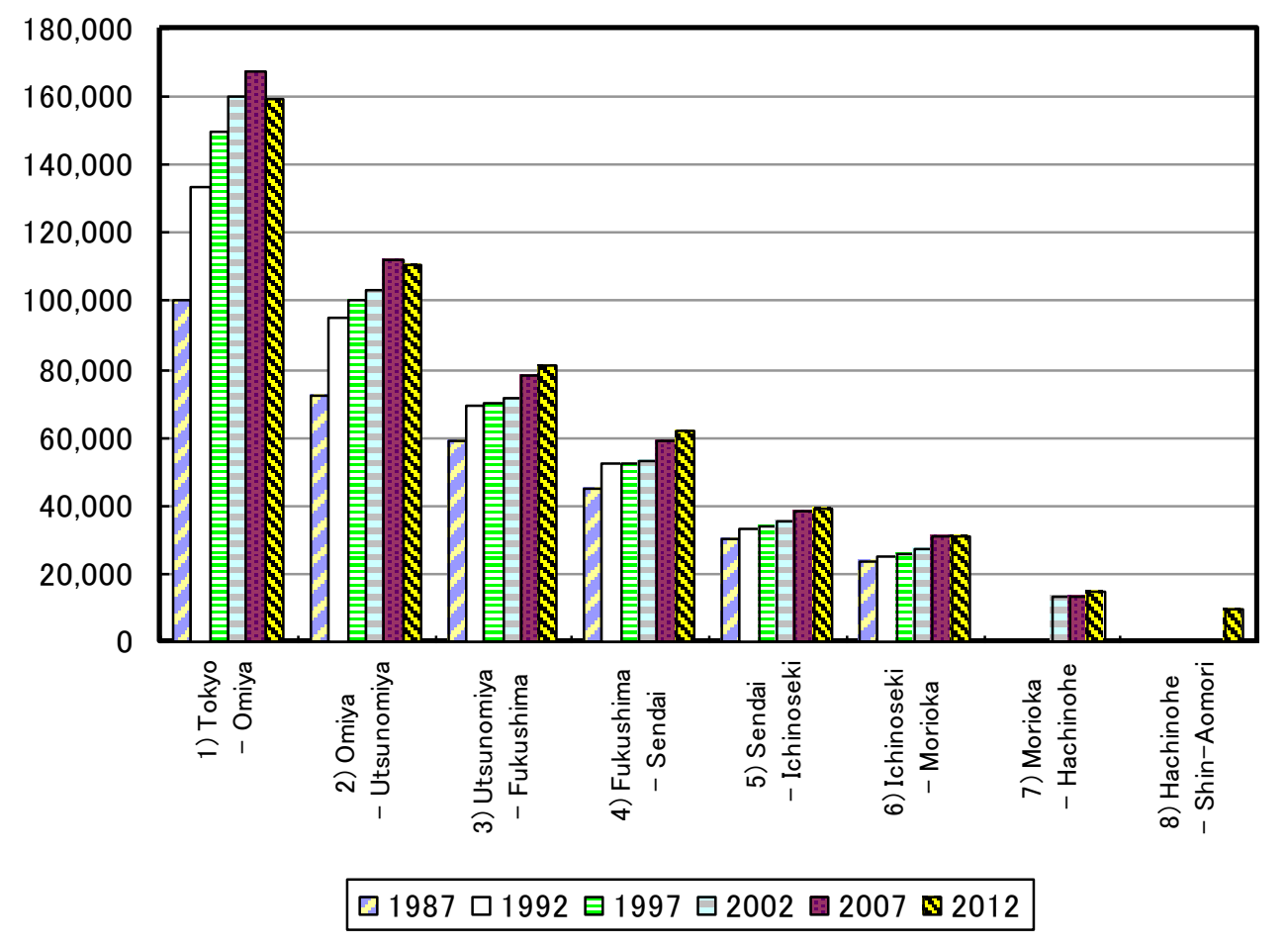

Source: JR East (2013) 
Table 6 examined how the traffic density of each section has increased from 1987 to 2012 . It shows that the sections closest to Tokyo have increased in ridership much more than the other sections further from Tokyo.

Table 6. Increase of Traffic Density of the Tohoku Shinkansen Line 1987 to 2012

\begin{tabular}{|c|c|c|c|c|c|}
\hline \multirow{2}{*}{ No } & \multicolumn{3}{|c|}{ Section between Station (A) and Station (B) } & \multicolumn{2}{c|}{$\begin{array}{c}\text { Increase of Traffic Density from } \\
1987 \text { to } 2012\end{array}$} \\
\cline { 2 - 6 } & Station (A) & Station (B) & $\begin{array}{c}\text { Distance to Station (B) } \\
\text { from Tokyo Sta. } \\
\text { approximate time) }\end{array}$ & $\begin{array}{c}\text { Increase of Traffic } \\
\text { Density } \\
\text { (passengers/day) }\end{array}$ & $\begin{array}{c}\text { Increase } \\
\text { Rate (\%) }\end{array}$ \\
\hline 1 & Tokyo & Omiya & $30 \mathrm{~km}(0.4 \mathrm{H})$ & 59556 & 59.5 \\
\hline 2 & Omiya & Utsunomiya & $110 \mathrm{~km}(0.8 \mathrm{H})$ & 38489 & 53.1 \\
\hline 3 & Utsunomiya & Fukushima & $273 \mathrm{~km}(1.6 \mathrm{H})$ & 22173 & 37.7 \\
\hline 4 & Fukushima & Sendai & $352 \mathrm{~km}(1.7 \mathrm{H})$ & 17174 & 38.2 \\
\hline 5 & Sendai & Ichinoseki & $445 \mathrm{~km}(2.3 \mathrm{H})$ & 8495 & 28.0 \\
\hline 6 & Ichinoseki & Morioka & $535 \mathrm{~km}(2.5 \mathrm{H})$ & 7995 & 34.3 \\
\hline 7 & Morioka & Hachinohe & $632 \mathrm{~km}(3.1 \mathrm{H})$ & 14758 & $8.9 * 2$ \\
\hline 8 & Hachinohe & Shin-Aomori & $714 \mathrm{~km}(3.2 \mathrm{H})$ & 9453 & - \\
\hline
\end{tabular}

*1: Travel time varies depending on the types of trains.

*2: This figure is the increase rate since the first days after opening.

Source: Calculation based on JR East (2013) and JR Group (2013)

In the same way, Figure 9 shows traffic density of the Joetsu Shinkansen Line (by section) and the Hokuriku Shinkansen Line. 
Figure 9. Traffic Density of the Joetsu and Hokuriku Shinkansen Lines (Passengers / day)

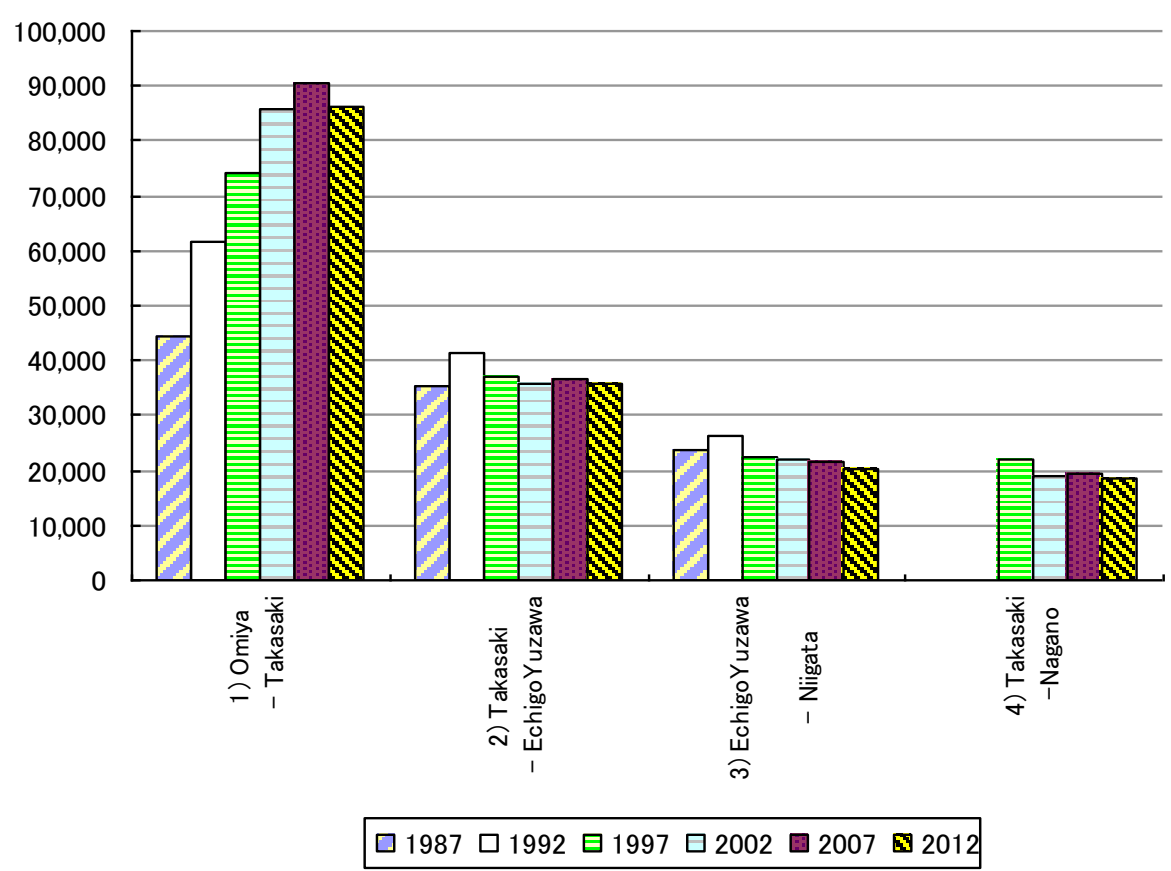

Source: JR East (2013)

Figure 9 shows that the section closer to Tokyo, between Omiya and Takasaki, on the Joetsu Shinkansen Line has more ridership than the other sections further from Tokyo.

Table 7, which shows the changes in traffic density of each section, also indicates that the section closer to Tokyo has increased its traffic density largely. As opposed to this, the sections further from Tokyo lessened their traffic density during the years as shown in the segment between Echigo-Yuzawa and Niigata in the Tohoku Shinkansen Line and the segment between Takasaki and Nagano in the Hokuriku Shinkansen Line.

Table 7. Increase of Traffic Density of the Joetsu and Hokuriku Shinkansen Lines (1987 to 2012)

\begin{tabular}{|c|c|c|c|c|c|}
\hline \multirow{2}{*}{ No } & \multicolumn{3}{|c|}{ Section between Station (A) and Station (B) } & \multicolumn{2}{|c|}{$\begin{array}{l}\text { Increase of Traffic Density } \\
\text { from } 1987 \text { to } 2012\end{array}$} \\
\hline & Station $(A)$ & Station (B) & $\begin{array}{l}\text { Distance to Station (B) } \\
\text { from Tokyo Sta. } \\
\text { (approximate time) }{ }^{* 1}\end{array}$ & $\begin{array}{l}\text { Increase of Traffic } \\
\text { Density } \\
\text { (passengers/day) }\end{array}$ & Increase Rate (\%) \\
\hline 1 & Omiya & Takasaki & $105 \mathrm{~km}(0.8 \mathrm{H})$ & 41826 & 94.1 \\
\hline 2 & Takasaki & Echigo-Yuzawa & $199 \mathrm{~km}(1.2 \mathrm{H})$ & 208 & 0.6 \\
\hline 3 & Echigo-Yuzawa & Niigata & $334 \mathrm{~km}(2.0 \mathrm{H})$ & $-3,224$ & -13.7 \\
\hline 4 & Takasaki & Nagano & $222 \mathrm{~km}(1.4 \mathrm{H})$ & $-3,430$ & $-15.6 * 2$ \\
\hline
\end{tabular}

${ }^{*} 1$ : Travel time varies depending on the types of trains.

*2: This figure is the increase rate since the first days after opening.

Source: Calculation based on JR East (2013) and JR Group (2013) 
The above statistics clearly show that the section closer to Tokyo metropolitan area not only has large transport volume but also has been increasing its ridership further since opening of the lines.

In relation to this change, Figure 10 shows the average number of Shinkansen commuting passes sold in a month, and the figure shows that the number has been increasing steadily.

Railways, including high-speed railways, have significant external effects such as increasing the land values along the lines. This means that people prefer to live around stations, and railway lines serve to develop residential/commercial areas around stations. The increase of the Shinkansen commuting passes sold, shown in Figure 10, provides evidence that Shinkansen has expanded the commutable area especially around metropolitan areas.

Figure 10. Average Sale of Shinkansen Commuter Passes Per Month *

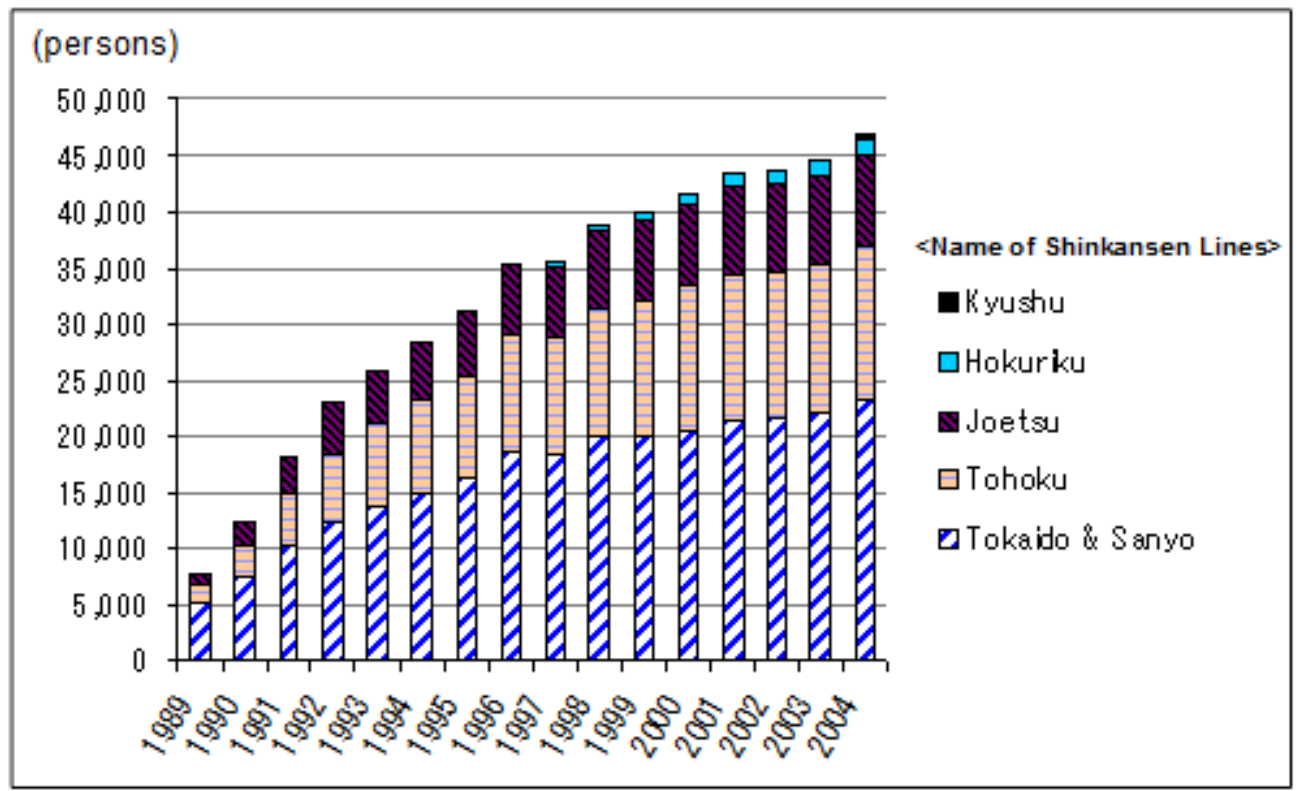

*: The statistic shows the number of commuters.

A pass valid for three months is counted here as three one-month passes.

Source: MLIT (2013)

\subsection{Evaluation of the Performance with Conventional Railways}

This section compares the performance of Shinkansen Lines with conventional lines in each JR passenger company. Figure 11 shows 1987 and 2011 revenues from Shinkansen and conventional lines in the three companies. 
Figure 11. Changes in Revenue from Shinkansen and Conventional Lines

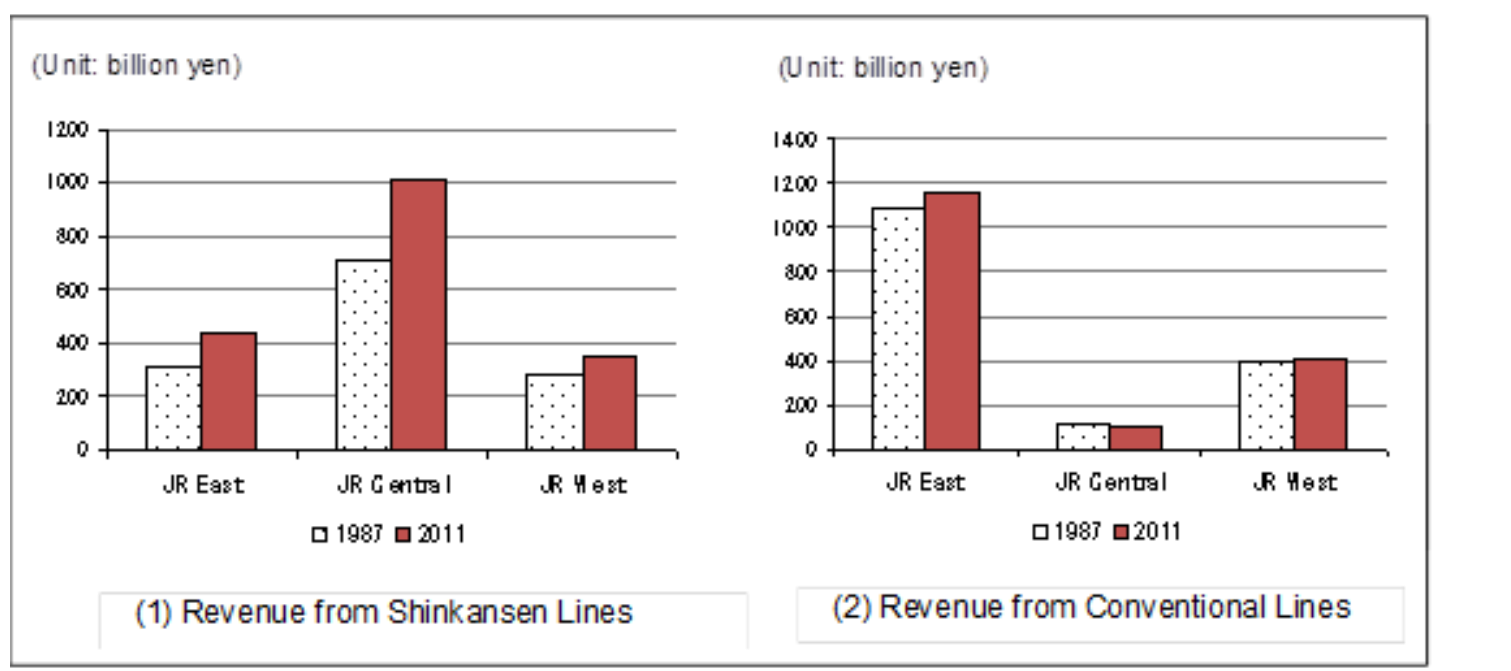

Source: JR East (2012), JR Central (2013a), JR West (2013)

Figure 11 shows that the revenue from Shinkansen Lines has increased to a large extent in all the three companies since the establishment of the companies in 1987. It is worth noting that JR Central and JR West have attained the increase without extending new segments of Shinkansen lines since 1987. In addition, the increase in Shinkansen lines is in contrast to the situation on the conventional lines, where revenues have been stable or show a slight decrease.

As a result of these changes, the Shinkansen share of the total revenue has also increased in all the three companies. Table 8 shows the change in the share of Shinkansen lines' revenue in total transport revenue in each company.

Table 8. Share of Revenue and Rolling Stock Kilometers of Shinkansen Operation

\begin{tabular}{|l|c|c|c|}
\hline \multirow{2}{*}{} & \multicolumn{2}{|c|}{$\begin{array}{c}\text { Shinkansen Share of } \\
\text { Transport Revenue *1 }\end{array}$} & $\begin{array}{c}\text { Shinkansen Share of } \\
\text { Rolling Stock Kilometers *2 }\end{array}$ \\
\cline { 2 - 4 } & $\mathbf{1 9 8 7}$ & $\mathbf{2 0 1 1}$ & $\mathbf{2 0 1 1}$ \\
\hline JR East & $22 \%$ & $28 \%$ & $20 \%$ \\
\hline JR Central & $87 \%$ & $91 \%$ & $81 \%$ \\
\hline JR West & $42 \%$ & $46 \%$ & $37 \%$ \\
\hline
\end{tabular}

*1: Shinkansen revenue / total transport revenue

*2: Shinkansen rolling stock kilometers / total rolling stock kilometers

Source: Calculation based on JR East (2012), JR Central (2013b), JR West (2012; 2013)

To compare the effectiveness of Shinkansen operations, Table 8 also listed the share of Shinkansen's rolling stock kilometers compared with total rolling stock kilometers. It shows that the share of revenue is higher than the share of rolling stock kilometers in terms of Shinkansen operation of each company. This means that if rolling stock $\mathrm{km}$ is taken as the basic unit, a unit of Shinkansen operation brings in more revenues to the company than a unit of conventional train operation. 
The results of this section show that, despite the severe competition from other transport modes, Shinkansen operation retains its competitiveness and has been increasing its transport volume, especially in the segments close to metropolitan areas. In terms of the revenue per rolling stock kilometer, Shinkansen operation is a better revenue earner than conventional train operation.

\section{CONCLUSIONS}

High speed railway system, initially introduced by JNR in 1964, has been extended and now covers most of Japan. As JNR was reformed in 1987, the schemes for construction and operation were also modified accordingly. At present, the construction of the system is implemented as a public works project, and it is mostly financed by the public sector without adversely affecting the financial situation of each railway company.

Although the operation has been divided into independent companies, many Shinkansen trains are operated smoothly over tracks of two of these companies. Although the new segments constructed since JNR reform have a vertically separated structure, each railway company controls its entire system. This is also the case for the operation of through-train services crossing the borders between companies. This way of train operation is in stark contrast to the recent European railway operation.

It is true that Shinkansen operation has large impacts on the social and economic development. For example, it provides economic benefits such as raising real estate value, easing highway congestion, stimulating job creation, etc. In order to evaluate the effectiveness of the project, it is of course necessary to include these social and economic benefits.

But, to narrow the focus, this paper primarily discussed Shinkansen's effects on the operating companies. The paper examined the changes in transport on each Shinkansen line opened so far, and found that the traffic density of Shinkansen lines varies to a large extent depending on the lines and segments.

Since it is difficult to allocate the overhead expenses, each JR company does not publicise the profitability of each line. Thus, based on the financial change of the companies, this study tried to evaluate the financial effects of Shinkansen operation depending on its traffic density.

The study also showed that Shinkansen transport is competitive against other transport modes and is increasing its transport revenue by a much higher rate than conventional lines operated by those railways. Along with the increase of the inter-city passengers as shown in the Tokaido and Sanyo Shinkansen Lines, the number of Shinkansen commuters has been also increasing especially around Tokyo metropolitan area. Owing to its competitiveness, the share of revenue brought from Shinkansen operation has been increasing in those railway companies in Japan. 


\section{REFERENCES}

Aoki, E. et al. (2000), A History of Japanese Railways 1872-1999, East Japan Railway Culture Foundation

Institute of Transportation Statistics (1995), JNR Annual Railway Statistic (Kokuyu Tetsudou Tetsudou Toukei Ruinen Hyou), Institute of Transportation Statistics

JNR (1985), JNR Audit Report, Japanese National Railways

JNR (1986), JNR in terms of Figures (Suuji de Mita Kokutetsu), Japanese National Railways

JR Central (2007), 20 Year History of JR Central (Tokai Ryokaku Tetsudou 20 Nenshi), JR Central

JR Central (2013a), Annual Report 2013, JR Central

JR Central (2013b), Central Japan Railway Company Fact Sheets 2013, JR Central

JR East (2004), On Track for World No.1 Annual Report 2004, JR East

JR East (2012), 2012-2013 Corporate Profile, JR East

JR East (2013), Home page of JR East, Available from World Wide Web: http://www.jreast.co.jp/ rosen_avr/pdf/1987_2012.pdf

JR Group (2013), JR Timetable (JR Jikoku Hyou), Koutsu Shinbunsha

JR West (2012), A Financial Statement of JR West 2011 (Yuuka Shouken Houkokusho), JR West

JR West (2013), JR West in terms of Data 2013 (Data de miru JR Nishinihon 2013), JR West

Kurosaki, F. (2008), An Analysis of Vertical Separation of Railways, ITS Thesis, University of Leeds

Kurosaki, F. and K. Okuda, (2012), On-Rail Competition in Korea: A Comparison with Railways in Japan and Europe, EASTS Journal (to be published on 27 Dec. 2013)

MLIT (2013), Railways in terms of the Figures (Suuji de Miru Tetsudou 2012), Institute for Transport Policy Studies

Sumita, S. (2005), About the Shinkansen Holding Corporation Again (Hutatabi Shinkansen Hoyuukikou ni tsuite) Transportation \& Economy, No.65, April, 2005. pp.55-57 

